UDK $37.02: 3+5$

UDK $37.016: 3+5$

Ирена Б. Голубовић-Илић irena.golubovic@pefja.kg.ac.rs (Педагошки факултет, Јагодина)

\title{
ДИДАКТИЧКО-МЕТОДИЧКЕ СПЕЦИФИЧНОСТИ ПРИМЕНЕ ЛАБОРАТОРИЈСКО-ЕКСПЕРИМЕНТАЛНЕ МЕТОДЕ И ИСТРАЖИВАЧКОГ ПРИСТУПА У НАСТАВИ ПРИРОДЕ И ДРУШТВА
}

\begin{abstract}
Сажетак: Једна од могућности да се отклоне и превазиђу бројне слабости уочене у настави Природе и друштва, а знања ученика о појавама, процесима и односима у свету који их окружује учине трајнијим и квалитетнијим, јесте примена истраживачког приступа и лабораторијско-експерименталне методе. У раду објашњавамо структуру, дидактичко-методичке специфичности и организацију часова на којима је ова метода заступљена, последице њене неадекватне и недовољне примене и наводимо садржаје предмета Свет око нас/ Природа и друштво које сматрамо погодним за примену таквог начина рада.
\end{abstract}

Кључне речи: лабораторијско-експериментална метода, истраживачки приступ, организација часа, Природа и друштво, наставни садржаји.

У документима који се односе на образовање (курикулумима, декларацијама, повељама, образовним стандардима и др.) у многим земљама истичу се значај и потреба да се настава и учење природних наука реализују кроз истраживачки приступ. Такав захтев повезан је са експерименталном природом ових наука, тј. са основним начином сазнавања у природним наукама. У учионици, ученици би требало да до сазнања долазе посматрањем појава, процеса и односа око себе, да прикупљају податке у експерименталном раду, уочавају правилности 
међу подацима, да формулишу претпоставке, проверавају их путем експеримента, да дају објашњења и изводе закључке. Упркос томе, у већини наших школа настава Света око нас/ Природе и друштва реализује се на традиционалан начин - коришћењем вербалних метода рада, уџбеника и понекад методе показивања. Постојећа ситуација се углавном оправдава слабом и неадекватном опремљеношћу школа потребним материјалима и наставним средствима. Резултат такве наставе је да ученици немају квалитетна знања о свету који их окружује, не схватају садржаје предвиђене наставним програмом, усвајају их без разумевања, не виде њихову сврху, значај и везу са свакодневним животом, што често има за последицу и негативан став према предмету.

С обзиром на то да се суштина савремене наставе, па и наставе Природе и друштва, огледа у томе да се из наставног процеса све више потискују вербализам, механичко памћење градива, методе и облици рада у којима су ученици пасивни, потребно је интензивирати и подстицати примену метода и наставних стратегија које доприносе да ученици на часовима буду што активнији. У настави би требало користити оне наставне методе код којих је акценат на осамостаљивању ученика, на оспособљавању за коришћење различитих извора знања, на повезивању стечених знања из различитих области, на практичној примени знања приликом решавања проблема у свакодневном животу и стварању (обезбеђивању) услова за што разноврсније и креативније учешће ученика у наставном процесу.

Сам избор наставних метода и њихова комбинација нимало не обезбеђују успешну обраду наставних садржаја. Успех и пожељни васпитно-образовни ефекти обезбеђују се добром методичком поставком и њеном стваралачком реализацијом. Сваки покушај да се нека од наставних метода окарактерише као добра или лоша није 
педагошки оправдан. Веома често нека ‘стара' и 'одбачена'метода може добити свежину и постати веома ефикасна у настави. Функционалност и вредност методе није у њој самој, већ у околностима њене примене и умећу којим се примењује (Вилотијевић 1999). Због тога је важно да наставник теоријски добро познаје све наставне методе које му 'стоје на располагању', али да је и практично оспособљен да на различите начине, у ситуацијама и околностима које могу бити јако променљиве, прилагоди свој начин рада условима који то налажу. С обзиром на то да се од система образовања данас очекује да оспособљава појединце који умеју „да се баве иновацијама, да се развијају, да се прилагођавају свету који се брзо мења и да усвоје те промене” (Делор 1996: 63), сасвим је разумљиво што се и од наставника очекује да, пребацујући се са улоге 'солисте' на улогу 'пратње', нагласак уместо на ширење и преношење одређених знања, стави на пружање помоћи ученицима, „као и да ученике више воде него обликују” (Делор 1996: 134). У том контексту једна од могућности иновирања и интензивирања наставе Природе и друштва јесте примена лабораторијско-експерименталне методе.

Лабораторијско-експериментална (у даљем тексту ЛЕ) метода, која се у нашој дидактичко-методичкој литератури јавља под различитим називима - лабораторијска, метода експерименталних радова, метода лабораторијских и практичних радова, метода практичних радова, метода истраживања и сл., подразумева да ученици сами (индивидуално, у пару или у групама) изводе експерименте, одређене поступке и операције (скицирање, бележење, закључивање, упоређивање, извештавање) и самостално посматрају предмете, појаве и процесе у свом окружењу. Сам назив лабораторијски рад требало би условно схватити, јер се ти радови, посебно у разредној настави, не морају одвијати у лабораторији, 
већ „у разредној учионици, специјализираној учионици, кабинету, помоћним школским просторијама, школском врту, природи, свуда гдје ученици/ ученице могу доћи у непосредан дотицај са стварношћу” (Де Зан 2005: 270). У настави природе и друштва примена ЛЕ методе подразумева „директан рад ученика са одређеним средствима и прибором на одређеном материјалу” (Лазаревић и Банђур 2001:136), а задатак наставника који планира да примени ову методу на часу веома је озбиљан и сложен. Он, поред пажљивог анализирања наставних садржаја и издвајања наставних јединица које су погодне да се обраде овом методом, подразумева и претходно обезбеђивање потребне опреме, апарата и материјала и темељну припрему ученика. Сасвим је нереално очекивати да ће се способности ученика за овакав начин рада са узрастом ученика спонтано развити, па је неопходно на што ранијем узрасту (већ од првог разреда) почети са извођењем најједноставнијих експеримената, како би у даљем току школовања, из разреда у разред, повећањем захтева и усложњавањем задатака, ученици били оспособљени за самосталну примену поменуте методе (Голубовић Илић 2010: 105).

Упркос томе што је настава применом ЛЕ методе прилично захтевна јер тражи, у односу на примену неких других метода, више времена, одређене услове, додатне трошкове за набавку и припрему материјала, опсежну и детаљну претходну припрему наставника и ученика, постоје веома озбиљни разлози за њену све чешћу примену у наставној пракси, посебно у настави Света око нас/ Природе и друштва. Интересантни по својим циљевима, привлачни по материјалу и прибору који се употребљава приликом њиховог извођења, погодни за подстицање радозналости и 'разбијање’ монотоније у току наставе, лабораторијски и практични радови обогаћују наставни процес и доприносе његовом интензивирању. Поред тога, предности, ефекти 
и резултати који се у односу на друге методе постижу у настави применом ЛЕ методе су бројни, како са становишта савремене наставе, тако и са становишта способности и карактеристика ученика које се њеном применом развијају.

Резултати емпиријских истраживања (Цвјетићанин и Сегединац 2007; Цвјетићанин и др. 2008; Марковић и др. 2006; Кука 2000; 1999) показују да је настава изведена применом ЛЕ методе ефикаснија у односу на класичну вербално-текстуалну наставу, не само у разредној, већ и у предметној настави. Часови на којима доминира самосталан рад ученика на огледима - извођење експеримената показују да су доминантне активности ученика провокативне и атрактивне, да ангажују различите аспекте личности детета, омогућавају да ученик доведе у везу своја искуства са новим сазнањима, поштују богатство индивидуалних разлика, омогућавају вербалну интеракцију између ученика и мотивишу их да властитом активношћу долазе до нових сазнања. Предност експеримента је у томе што се може извести неколико пута, уз варирање услова и измену одређених фактора, чиме се изучавана појава или процес детаљније сагледавају, анализирају, док су знања усвојена на тај начин потпунија и дуже одолевају процесу заборављања. ЛЕ метода поред осамостаљивања ученика, њиховог оспособљавања за прикупљање различитих података и коришћење различитих извора информација, доприноси и развијању хипотетичког и критичког мишљења, развијању способности објашњавања, тумачења и извођења закључака, што су све елементи савремене концепције наставе. Резултати су показали да се „кроз самостални експериментални рад ученика и истраживачки приступ развија највећи број интелектуалних и практичних способности ученика" (Марковић и др. 2006: 413).

Поред тога, предности, односно резултати који се у односу 
на друге методе постижу у настави Природе и друштва применом експеримената су боље разумевање природе - појава, процеса и односа у њој; подстиче се и буди интелектуална радозналост ученика; повећава мотивација и жеља за сазнавањем непосредног окружења; знања су трајнија, јер ученик учи деловањем, уочава јединство материје, схвата везу између живе и неживе природе, боље уочава и разуме природне узрочно-последичне везе и односе; подстиче се трансформисање стечених знања у вештине и навике; ученик боље разуме свет око себе; развијају се естетске навике и машта ученика; развија се одговорност ученика према животној средини (Цвјетићанин 2007).

Орагнизаџија часа применом лабораторијско-експерименталне методе

Да би се детаљно могле сагледати одређене дидактичкометодичке специфичности организације часа на коме је заступљена ЛЕ метода, требало би првенствено размотрити његову унутрашњу структуру. Најчешће методичке компоненте које чине организациону структуру часа на коме ће бити примењена ЛЕ метода су следеће (Продановић 1974: 120):

а) избор проблема за експерименталну обраду,

б) израда концепције експерименталног рада,

в) утврђивање задатака и експерименталних фаза рада,

г) припрема и распоред експерименталног прибора и материјала,

д) експериментални рад и евиденција података и

ђ) сређивање добијених података.

Поменуте етапе Ладислав Богнар назива нешто другачије - 
договор, реализација (обухвата организацију и извођење) и евалуащија (Матијевић и Богнар 2002: 203), али је суштина рада у оквиру етапа јако слична онима које наводи Продановић. Број наведених етапа, њихово смењивање, редослед у току часа, временско трајање и међусобно усклађивање и интегрисање одређује наставник. Унутар сваког часа јављају се као његове оперативне временске јединице уводни, централни (средишњи или главни) и завршни део часа, а структура часа на коме ће бити примењена ЛЕ метода графички би се могла представити на следећи начин:

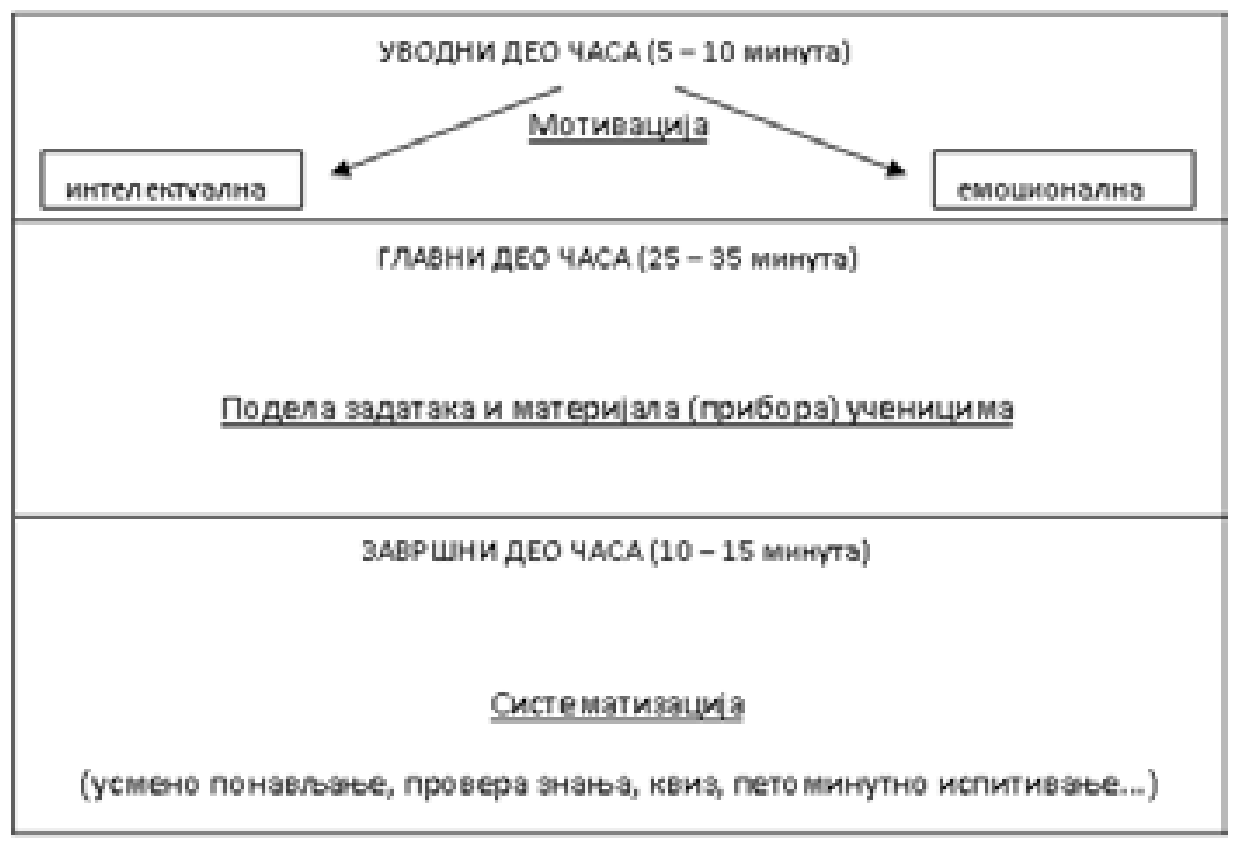

(према Банђур и Благданић 2007)

Саставни део уводног дела часа, непосредно пре самог извођења лабораторијских и практичних радова, јесте и давање инструкција ученицима о томе шта ће, како и зашто радити на часу. Временско трајање тог дела сасвим је релативно и зависи од узраста ученика, њихових способности и дотадашњег искуства у раду 
овом методом, али и од тога на који начин је наставник планирао и осмислио реализацију часа. Да би час био успешан, веома је важно дати ученицима детаљна упутства и прецизно (посебно када је реч о диференцираним задацима) објаснити шта су њихови задаци, јесу ли међусобно повезани, која је њихова сврха, значај и слично. Уколико су задаци сложенији, ученици (појединци, парови или групе) добијају писана (или штампана) упутства са задацима, па је у таквим ситуацијама веома важно развити навику ученика да пре самог почетка рада пажљиво и детаљно проуче упутства и благовремено проверити јесу ли их добро разумели. У случају да је наставник планирао да на часу буде заступљен групни облик рада или рад у паровима, посебан аспект на који би требало обратити пажњу је начин формирања група, односно парова, јер су успех читавог часа и квалитет усвојених знања често условљени структуром група и парова. Такође, ако је у плану коришћење одређеног прибора и алата (маказа, ножева, шила, игала и сл.), потребно је ученике упозорити и скренути им пажњу да приликом извођења огледа буду обазриви. Сав потребан прибор, материјал и реквизите које ученици непосредно користе приликом извођења огледа требало би претходно распоредити на клупи тако да им сваког тренутка буду доступни. Све огледе које је планирао да ученици ураде у току часа, наставник би требало да пре часа провери и изведе, водећи рачуна о њиховом трајању и евентуалним тешкоћама на које би ученици током извођења могли да наиђу.

Колико је за примену лабораторијског рада изузетно значајна припрема и наставника и ученика, показује чињеница да неки аутори (Де Зан 2005) у припремању наставног процеса издвајају и разликују: материјално-техничку (подразумева обезбеђивање материјалних и техничких услова за несметано одвијање наставног процеса), методичку (обухвата избор одговарајућих методичких поступака), 
спознајну (која се састоји од понављања релевантног наставног градива потребног као предзнање за усвајање нових садржаја) и психолошку припрему (подразумева мотивисање и подстицање ученика на активност у даљем току часа). Само добра и свестрана припрема свих учесника у наставном процесу може обезбедити сигуран и ефикасан рад.

У главном делу часа ученици самостално, у паровима или групама реализују предвиђене задатке директним радом са одређеним средствима и прибором на одређеном материјалу, при чему посебну пажњу, поред стицања знања, треба посветити оспособљавању ученика и развијању „вештина руковања одређеним алатом, прибором и инструментима". (Лазаревић и Банђур 2001:137) Суштину примене ЛЕ методе представља, дакле, извођење огледа. Оглед или експеримент подразумева вештачко стварање услова или изазивање неких појава и процеса ради њиховог детаљнијег проучавања. Да би сви ученици били, колико је то могуће, подједнако ангажовани у току рада, посебно када је у питању рад у пару и групама, требало би инсистирати на подели задужења (радних задатака) међу ученицима. Када проуче упутства за рад и добијена задужења (задатке, проблеме које треба да реше), од ученика би, посебно када су у питању сложенији огледи, требало захтевати да, пре самог извођења огледа, направе план рада и да своје идеје запишу или илуструју у свескама. На овај начин интензивира се интеракција међу ученицима, подстичу мисаони процеси, развија логичко мишљење, ученици оспособљавају за тимски рад и сарадњу, за визуелно и текстуално представљање својих мисли и идеја и подстиче правилан социо-емоционални развој детета. (Крнета 2007: 84) У овој тзв. оперативној фази часа наставник обилази ученике, прилази појединцима, групама или паровима, разговара са њима о задатку који су добили, помаже, сугерише, даје 
ближа одређења и смернице, док ученици изводе експерименте, посматрају, одговарају на питања, решавају задатке, праве белешке, илуструју, проучавају литературу, трагају за решењима проблема и слично, у зависности од тога шта је наставник планирао и задао им на почетку часа. Наставникова улога у овој етапи рада огледа се у томе да обилази, надгледа, контролише, помаже тамо где је неопходно, даје додатна упутства и инструкције, води рачуна да су сви ученици активни и усмерава њихов рад ка остваривању постављених циљева и задатака. Ученицима треба дати и могућност да се у току часа, када то прилике (природа задатака) и околности захтевају, слободно крећу по учионици и свим другим просторијама како би постављене задатке успешно урадили. Пожељно је да учионице у којима се одвија ЛЕ рад буду са покретним намештајем, како би се неометано премештали, да би сваки пар или група имали свој кутак (физички одвојен од осталих) и да једни друге не би међусобно ометали, деконцентрисали, скретали пажњу и слично.

Извођење огледа треба да прате само неопходна објашњења. Оно што је очигледно из самог огледа не би требало објашњавати. Наставникови коментари, сугестије и савети требало би да буду кратки и јасни. Уколико се догоди да неки оглед, и поред детаљне припреме, не успе, требало би га још једном поновити уз одговарајуће образложење и евентуално пружање помоћи ученицима приликом извођења. Грешка се може догодити и из техничких разлога, када би тај оглед ваљало заменити резервним огледом те врсте. Након огледа реч добијају ученици. Рад би требало осмислити тако да се са извођењем огледа започне у исто време, али да се извештавање и извођење закључака реализују тако да у њима учествују сви ученици. Своја запажања и закључке ученици би требало да изложе пред целим одељењем, док се од наставника очекује да, пажљиво бираним 
и прецизно формулисаним питањима помогне ученицима да уоче проблем, детаљно сагледају одређену ситуацију, да разумеју и схвате узрок и последицу, изведу закључке и постепено откривају и усвајају нова знања. Суштина је да се ученицима готова знања не саопштавају, већ да се серијом унапред припремљених и осмишљених питања њихове мисли усмере ка одређеном проблему, теми, законитости, процесу.

У завршном делу часа (неки аутори га називају и фазом интеграције), који се реализује фронталним обликом рада, врши се извештавање о оствареним резултатима рада, комбиновање и компоновање заједничког и/или појединачних извештаја, критичко претресање и усвајање закључака, размена искустава са другим паровима/ групама, (пр)оцена и евалуација рада групе/одељења у целини и њених појединих чланова и евентуално давање предлога за даљи рад на одређеном проблему, теми и сл. У овом делу часа унапред одређени (вође група), од стране својих другова предложени, изабрани или тог тренутка прозвани ученици објашњавају својим друговима шта је био њихов задатак и до којих су закључака дошли у свом раду. Уколико је потребно и не захтева много времена, извођење појединих експеримената и практичних радова може се поновити пред целим одељењем, нарочито ако ће позитивно утицати на квалитет знања и разумевање одређених појава и процеса од стране осталих ученика који такав задатак нису имали. Том приликом подстиче се разредна дискусија, врши допунско тумачење појединих делова градива, уклањају и попуњавају евентуалне празнине у извештајима и, када је реч о диференцираном раду, поједини закључци повезују у јединствену целину. Осећање задовољства због успешно остварених задатака и активности повећава осећање сигурности код ученика, осећање личне вредности, самопоштовања и самопоуздања, што ће 
се позитивно одразити на укупан развој њихове личности. Уколико је на часу био заступљен диференциран рад, резултати се обједињују на нивоу целог одељења и постају обавезни у смислу њиховог познавања и практичне примене за све парове, групе и појединце. Подаци се доводе у органску везу, истичу и наглашавају узрочно-последичне везе и односи, а закључци се обично исписују на табли, тако да их сви ученици, без обзира које су радне задатке имали, могу схватити, усвојити и трајно запамтити.

Каоједан одзначајних елемената реализације наставе применом ЛЕ методе, који позитивно утиче на развој конативне структуре личности ученика, наводи се и распремање прибора и материјала за рад. Применом ЛЕ методе код ученика се развија својеврсна радна дисциплина и експериментална култура која се огледа у пажљивом руковању прибором и материјалима, чувању опреме, придржавању правила и савета наставника у вези са начином реализације огледа, одржавању реда и чистоће клупа и учионице, поспремању опреме на одговарајуће место и томе слично.

Избор наставних садржаја погодних за примену лабораторијскоексперименталне методе

Имајући у виду да се циљеви наставе остварују реализацијом наставних садржаја, питање њиховог избора је од изузетне важности. Поред општих, као што су циљ васпитања и друштвене потребе, најважнијеодреднице изборанаставних садржаја сунаучнадостигнућа, индивидуалне потребе и сазнајне могућности ученика (Вилотијевић 1999: 7). Поред количине научних информација које се свакодневно увећавају, нека знања застаревају и постају неупотребљива, па је наставне садржаје потребно стално актуелизовати како би ученици 
били спремни за наредне образовне нивое и отворени за прихватање нових научних достигнућа. Узрасне могућности ученика такође су битан фактор избора садржаја, јер се у наставни програм не могу уносити они садржаји који немају ослонац у претходним знањима и когнитивним могућностима ученика, док су степен остваривања индивидуалних потреба и интересовања ученика, оптималног развоја њихових потенцијала и могућности мерило демократичности и прогресивности савремених образовних система.

Питање избора садржаја који ће се обрађивати истраживачким приступом и ЛЕ методом врло је деликатно и осетљиво. Наставник има задатак да пажљиво анализира наставни програм одређеног предмета (Свет око нас или Природа и друштво) и да евидентира, издвоји садржаје потенцијално погодне за примену ове методе. Том приликом потребно је да има у виду претходна знања, искуства и способности ученика, опремљеност школе наставним средствима и прибором за извођење огледа, број ученика у одељењу, њихове индивидуалне карактеристике, интересовања и др.

У прва два разреда ученици су у одређеној мери егоцентрични, мање навикнути и оспособљени за заједнички рад по групама, недовољно самостални, али та чињеница не би требало да обесхрабри учитеље у намери да примењују истраживачки приступ и ЛЕ методу на часовима Света око нас. Манипулативне способности ученика, спретност и вештине руковања одређеним прибором и материјалима, ${ }^{1}$ требало би постепено и систематски развијати. Од великог значаја су такође и способности сарадње у групи, расподеле задужења, прихватања одговорности, комуникативне вештине, способности посматрања, увиђања, упоређивања, извођења закључака,

\footnotetext{
1 Манипулативне способности ученика, спретност и вештине руковања одређеним прибором и материјалима на том узрасту (7-8 година) нису довољно развијене да би се истраживачки рад остваривао на адекватан начин.
} 
извештавања о постигнутим резултатима и многе друге за које се не може очекивати да ће се спонтано развити и са узрастом појавити. Проблеми који настају касније у трећем и четвртом разреду приликом примене истраживачких активности, великим делом су последица недовољне примене таквог начина рада у прва два разреда. Насупрот бројним, условно речено, отежавајућим околностима, постоје једноставни лабораторијски и практични радови (нпр. растварање соли у води, испитивање основних својстава материјала, прављење сенки различитих облика и величина) чијом реализацијом ће се ученици постепено оспособљавати, навикавати и развијати вештине и компетенције неопходне за нека каснија озбиљнија и сложенија истраживања и огледе. Садржаји који се у прва два разреда, по нашем мишљењу, могу успешно реализовати истраживачким приступом наведени су у табели 1:

Табела 1: Преглед садржаја предмета Света око нас погодних за реализащију ЛЕ методом

\begin{tabular}{|c|c|}
\hline Свет око нас, први разред & Свет око нас, други разред \\
\hline $\begin{array}{ll}\text { - } & \text { Основна својства воде: } \\
\text { различита стања, укус, мирис, } \\
\text { провидност } \\
\text { - } \quad \text { Осда као растварач } \\
\text { - } \\
\text { - Сирис, провијање ваздуха } \\
\text { - } \quad \text { Основна својства земљишта: } \\
\text { боја, растреситост, влажност } \\
\text { Материјали, њихова својства } \\
\text { (тврдо-меко, провидно- } \\
\text { непровидно, храпаво-глатко) и } \\
\text { понашање у води (плива-тоне, } \\
\text { растворљиво-нерастворљиво) }\end{array}$ & $\begin{array}{ll}\text { - } & \text { Где све има воде (облици } \\
\text { појављивања и основна својства } \\
\text { воде) } \\
\text { Променљивост облика и } \\
\text { слободна површина воде, } \\
\text { услови тока } \\
\text { Ваздух свуда око нас, ваздух - } \\
\text { услов живота } \\
\text { Како препознати ваздух (кроз } \\
\text { сопствено кретање и покретање } \\
\text { тела) } \\
\text { Промене које настају при } \\
\text { загревању и хлађењу воде и } \\
\text { ваздуха (промена температуре, }\end{array}$ \\
\hline
\end{tabular}




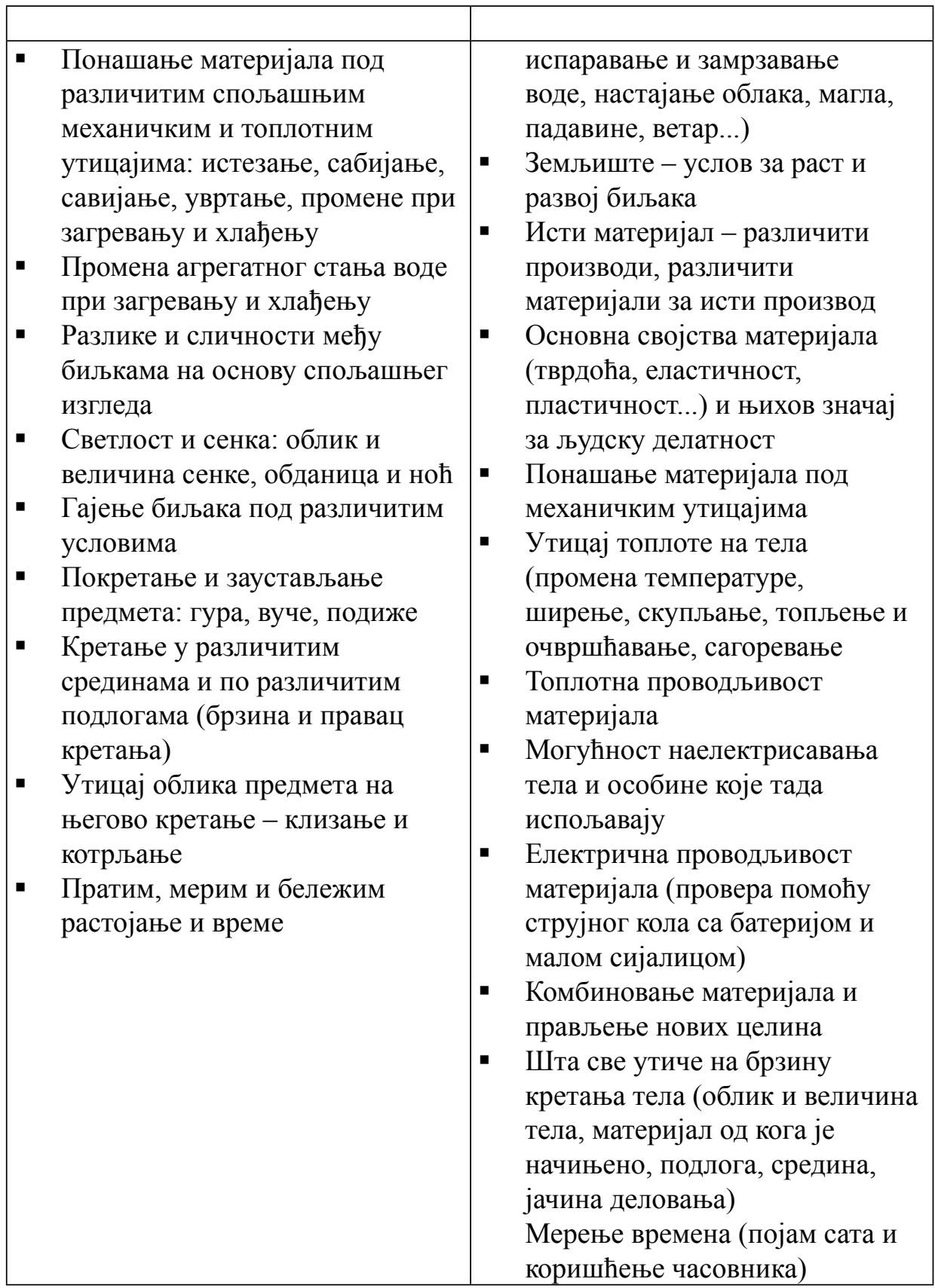


Истраживачки приступ заснован на самосталном истраживачком раду и примени ЛЕ методе при реализацији наведених садржаја може бити заступљен у појединим деловима часова (главном или завршном) у зависности од горе поменутих фактора узраста, предзнања, интересовања ученика, типа часа и др. У првом и другом разреду потребно је припремити више визуелних материјала и техничких средстава, примере у вези поступака рада давати пред целим одељењем, а објашњења тражити од ученика. На почетку ученике треба заинтересовати, прво за садржаје, а онда за путеве долажења до података и начине излагања (Шефер 1997: 601), а то се постиже одговарајућим избором истраживачких активности и једноставних огледа чијим реализовањем ће ученици доживети успех и задовољство новим сазнањем. У фокусутих првих, почетних научно-истраживачких корака и активности не би требало да су продукти, већ процес или пут долажења до сазнања. Ученике би првенствено требало ослободити и оспособити да проблемима приступају креативно и „схвате логику поступака којима се истраживачи, ствараоци данашње науке, користе да би откривали нове чињенице, законитости и принципе” (Исто 592).

Ученици трећег и четвртог разреда много су и сазнајно и психофизички зрелији за самосталну примену ЛЕ методе, међутим, уколико такав начин рада нису у довољној мери примењивали у претходним разредима, може се догодити да су у одређеној мери неспретни, спори и неефикасни. Последице недовољне примене ЛЕ методе и самосталног рада приликом усвајања знања из природе и друштва могу бити недостатак одговарајућих способности, вештина, умења и спретности када је у питању коришћење различитог прибора и материјала за извођење огледа, али и способности тимског рада које се односе на међусобну расподелу задужења, комуникацију са осталим члановима групе, повезивање претходних знања са новим 
подацима, њихово тумачење и извођење закључака. Ученицима који су навикли да на часовима природе и друштва, не улажући никакав мисаони напор, добијају готова знања, податке и чињенице које само треба да запамте, нови и другачији начин рада може представљати проблем. Истраживачки рад и примена ЛЕ методе захтева озбиљан напор и представља пут савладавања логичких правила и поступака креативног трагања за новим сазнањима, решењима проблема, законитостима, правилима. Ученици 3. и 4. разреда углавном су интелектуално тек у почетној фази развоја апстрактног мишљења, али правилно одабрани и савремено дидактички обликовани садржаји природе и друштва могу допринети развоју њихових бројних способности - когнитивних, социјалних, перцептивних, мануелних и др. Самосталан истраживачки рад не мора неизоставно увек да креира и иницира наставник. С обзиром на то да се такав рад, сем у оквиру редовне наставе, може одвијати и ван наставе - у виду припреме, на почетку обраде одређених садржаја, или као допунски рад којим ће се након обраде одређених садржаја потврдити или проширити усвојена знања, могућности његове реализације су врло широке. Место, начин, време и опсег истраживачких радова одређује наставник као организатор и руководилац наставног процеса, али идеје и предлоге могу давати и ученици у зависности од својих интересовања и могућности. Самостални истраживачки рад поред развоја научног погледа на свет, сазнавања принципа, законитости и материјалности објективне стварности, може допринети научном опредељивању ученика, успостављању правилног односа према научној делатности и подстицању на научни рад (Јукић и др. 1998: 111).

Садржаји предмета Природа и друштво у трећем разреду погодни за примену ЛЕ методе првенствено су све наставне јединице које припадају наставној теми Нежива природа, а затим и наставне 
јединице: Различити звуци у природи као последица кретања, Различити облици кретања и њихове основне карактеристике, Када и како тела падају, клизају се и котрљају наниже, Специфичне промене материјала под топлотним и механичким утицајима, Електрична проводљивост воде, водених раствора и ваздуха, Магнетна својства материјала (Службени гласник РС - Просветни гласник. 1/2005: 41 - 43). Када је у питању четврти разред, најпогоднијим за примену ЛЕ методе сматрамо наставне јединице у оквиру теме Истражујемо природне појаве (Службени гласник РС - Просветни гласник. 3/2006: 48) али се, свакако, списак погодних садржаја тиме не завршава, јер је добрим делом њихов избор условљен креативношћу, ентузијазмом и професионалном оспособљеношћу наставника.

Уместо закључка

Учење садржаја природних наука ${ }^{2}$ данашње време требало би да буде засновано на истраживачком приступу (Марковић и др. 2006: 412), с тим да се улога наставника са досадашње улоге предавача, преносиоца знања промени у улогу оног који води и усмерава ученике у процесу сазнавања. Један од примарних циљева којем теже бројна истраживања и различити покушаји осавремењавања наставе Природе и друштва јесте омогућавање и стварање услова ученицима да предвиђене садржаје усвајају на активан и ефикасан начин, односно да усвојена знања буду што трајнија и применљивија у различитим ситуацијама. Активан однос притом не подразумева искључиво манипулативни приступ настави и процесу учења (мада примена ЛЕ методе обухвата и тај сегмент), већ првенствено активности у погледу

\footnotetext{
2 Природне науке подразумевају и садржаје предмета Свет око нас и Природа и друштво који на известан начин представљају њихову основу (темељ) - примедба аутора
} 
мисаоно-логичког закључивања и разумевања. То подразумева да до сазнања о одређеним променама, појавама и процесима у свету који их окружује ученици долазе систематским посматрањем, прикупљањем одређених података, уочавањем правилности међу њима, формулисањем претпоставки и њиховом експерименталном провером (извођењем једноставних огледа), тумачењем и извођењем закључака. Садржаји наставе природе и друштва омогућавају да ученици природу схвате у сталним променама и кретањима, узрочно-последичној повезаности појава, процеса и односа живе и неживе природе, али и да развију различите способности, вештине и умења неопходне за решавање различитих проблема и сналажење у свакодневном животу. У том контексту дилема да ли на часовима поменутих предмета примењивати ЛЕ методу и истраживачки приступ не постоји, јер је то професионална обавеза, потреба и дужност наставника који треба и жели да свој посао обавља како ваља.

\section{ЛИТЕРАТУРА}

Банђур, Вељко, Благданић, Сања (2007). Практикум из Методике наставе природе и друштва. Ваљево: Merlin company.

Вилотијевић, Младен (1999). Дидактика - органиzаиија наставе. Београд: Учитељски факултет Београд / Завод за уџбенике и наставна средства.

Голубовић Илић, Ирена (2010). Лабораторијско - експериментална метода и вештине комуницирања потребне за њену успешну реализацију. Узданииа, VII (2): $101-117$

Делор, Жак (1996). Образовање скривена ризница. Унеско: Извештај међународне комисије о образовању за XXI век. Београд: Министарство просвете РСрбије.

Де Зан, Иван (2005). Методика наставе природе и друштва. Загреб: 
Школска књига.

Јукић, Стипан, Лазаревић, Живољуб, Вучковић, Весна (1998). Дидактикаизбор текстова. Јагодина: Учитељски факултет у Јагодини.

Крнета, Драгољуб (2007). Методе учења у свјетлу промјена у образовању. Иновације у настави. (1): 79-88

Кука, Мирослав (1999). Утицај лабораторијско-експерименталне методе на успех ученика у настави физике. Настава и васпитање. ( 3-4) : $327-351$

Кука, Мирослав (2000). Мотивисаност ученика да уче путем примене лабораторијско-експерименталне методе. Педагошка стварност. (1-2): $71-83$

Лазаревић, Живољуб и Банђур, Вељко (2001). Методика наставе природе u друштва. Јагодина/Београд: Учитељски факултет у Јагодини/ Учитељски факултет у Београду.

Марковић, Мирјана и др. (2006). Ефикасност различитих метода наставе и учења хемије у основној школи. Настава и васпитање. (4): 398-413. Матијевић, Милан и Богнар, Ладислав (2002). Дидактика. Загреб: Школска књига.

Цвјетићанин, Станко и Сегединац, Мирјана (2007). Примена експеримента у сазнајном процесу наставе познавања природе. Иновације $y$ настави. (3): 132-141.

Цвјетићанин Станко и др. (2008). Ставови ученика четвртог разреда основне школе о самосталном истраживачком раду у настави познавања природе. Настава и васпитање, (2): 157-164.

Продановић, Тихомир (1974). Методика наставе познавања природе. Београд: Завод за уџбенике и наставна средства.

Службени гласник РС - Просветни гласник. 1/2005: 41-43.

Службени гласник РС - Просветни гласник. 3/2006: 48

Шефер, Јасмина (1997). Евалуација ефеката учења научно-истраживачких поступака кроз групни рад у настави. Настава и васnumaње. (5): 591-610. 
Irena B. Golubović-Ilić

\section{DIDACTICAL AND METHODOLOGICAL SPECIFIC FEATURES OF THE APPLICATION OF LABORATORY-EXPERIMENTAL METHOD AND INQUIRY-BASED APPROACH TO TEACHING SCIENCE AND NATURE}

Summary: Students should be instructed in the ways in which scientific truths are reached as early as possible, so that they are able to grasp the complex system of knowledge about the natural and social environment. Their innate curiosity and the need to explore and study the world around them should be nourished and encouraged while Science lessons should include such teaching methods and strategies that provide opportunities for discovering, problem solving, experimenting, constructive and critical analysis, contemplation and interpreting certain phenomena and processes. Teaching Science in a classroom in which students are sitting properly while listening attentively to the teacher and memorizing the facts and information the teacher is presenting is considered traditional and it cannot meet the needs and challenges of the modern society. By using the laboratory-experimental method and inquiry-based approach that is theoretically grounded in today's widely accepted constructivist educational paradigm, Science lessons could become more modern, innovative and more intense. Being engaged in the activities generated from the inquiry-based method makes students more independent, helps them boost their self-confidence and also enables them to acquire knowledge in different ways. At the core of the scientific method is the view that knowledge must come as a consequence of personal observation, practical action and thinking, whereas learning is seen as finding and discovering.

The paper emphasizes the structure, didactical and methodological specific features and the organisation of Science and Nature classes by using the laboratory-experimental method and inquiry-based approach, the consequences of its inadequate and insufficient application and lists the contents of the subjects The world around us/ Science and Nature that we consider appropriate for the application of this teaching strategy.

Key words: laboratory and experimental method, the inquiry-based approach, the organisation of classes, Science and Nature, teaching contents 